\title{
Studi Variabel Makroekonomi dan Pengaruhnya terhadap Indeks Harga Saham Sektor Properti dan Real Estate di Bursa Efek Indonesia
}

\author{
Lisa Uswatun Hasanah ${ }^{1 *}$, Haryadi ${ }^{2}$, Emilia $^{3}$ \\ ${ }^{1,2,3}$ Prodi Ekonomi Pembangunan, Fakultas Ekonomi dan Bisnis, Universitas Jambi
}

\begin{tabular}{|l|l|l|l|} 
Diterima: 08-11-2021 & Direvisi: 28-11-2021 & Disetujui: 1-12-2021 & Dipublikasi: 31-12-2021 \\
\hline
\end{tabular}

\begin{abstract}
This research intends to analyze the effect of inflation, exchange rates, interest rate, and GDP growth on the property and real estate sector composite index in the Indonesia Stock Exchange. This research applies secondary data annual period 2000-2018sourced from the Central Agency on statistics, Bank Indonesia (Indonesian Economic and Financial Statistics and reports on the Indonesian economy), the Indonesia Stock Exchange (IDX) (IDX statistics), and other institutions related to research. The analysis is based on the Ordinary Least Square (OLS) method. The results showed that the independent variables simultaneously significantly affect the composite index of the property and real estate sector. In partial inflation, exchange rate and interest rate significantly impacted the composite index movement of the property and real estate sector. At the same time, GDP growth had no significant effect on the composite index of the property and real estate sector.
\end{abstract}

Keywords: inflation, exchange rates, interest rate, GDP growth,

\begin{abstract}
Abstrak
Penelitian ini bertujuan untuk menganalisis pengaruh inflasi, nilai tukar (kurs), tingkat suku bunga deposito dan pertumbuhan PDB terhadap pergerakan indeks harga saham sektor properti dan real estate di Bursa Efek Indonesia. Penelitian ini dilakukan dengan menggunakan data sekunder berupa data tahunan periode 2000-2018 yang bersumber dari Badan Pusat Statistik, Bank Indonesia (Statistik Ekonomi dan keuangan Indonesia dan laporan perekonomian Indonesial), Bursa Efek Indonesia (BEI) (IDX statistics) dan instansi lain yang terkait dengan penelitian. Alat analisis yang digunakan dalam penelitian adalah regresi linear berganda. Hasil penelitian menunjukkan bahwa variabel independen secara simultan berpengaruh signifikan terhadap pergerakan indeks harga saham sektor properti dan real estate. Secara parsial inflasi, nilai tukar, tingkat suku bunga deposito berpengaruh signifikan terhadap indeks harga saham sektor properti dan real estate, sedangkan pertumbuhan PDB tidak berpengaruh signifikan terhadap indeks harga saham sektor properti dan real estate.
\end{abstract}

Kata kunci: inflasi, nilai tukar (kurs), suku bunga deposito, pertumbuhan PDB,

\section{Pendahuluan}

Investasi adalah kegiatan penempatan dana pada satu atau lebih aset selama periode tertentu dengan harapan memperoleh penghasilan dan peningkatan nilai investasi. Dalam konteks ini, pasar modal adalah salah satu alternatif pilihan investasi yang dapat menghasilkan tingkat keuntungan optimal bagi investor. (Adam, dkk., 2013). Salah satu jenis instrumen investasi yang sering dilakukan adalah investasi saham. Menurut Fahmi (2015) saham merupakan tanda bukti penyertaan modal/dana pada suatu perusahaan. Dengan adanya penyertaan modal tersebut investor mendapat klaim atas pendapatan perusahaan.

\footnotetext{
* Penulis korespondensi

Email: uswatunlisa@yahoo.com
} 
Pasar modal Indonesia saat ini sangat berkembang, indikasi ini ditandai dengan semakin banyaknya investor yang berinvestasi pada pasar modal. Berdasarkan data yang diperoleh dari Otoritas Jasa Keuangan (OJK), pada tahun 2018 jumlah investor pasar modal mencapai 1.344.764 investor, meningkat sebesar 19,78\% dari tahun 2017 dimana jumlah investor pada tahun tersebut sebanyak 1.122.688 investor. Dari total investor tersebut terdapat 851.903 investor yang berinvestasi pada pasar saham, dengan rata-rata investor saham aktif harian sebanyak 40.072 investor. Saham merupakan salah satu instrumen investasi yang paling banyak dilakukan sepanjang tahun 2018. Tercatat sebanyak 2.536,28 miliar lembar saham yang diperjualbelikan sepanjang tahun 2018. Adapun jumlah emiten saham tercatat sepanjang tahun 2018 sebanyak 619 perusahaan.

Bursa Efek Indonesia saat ini memiliki 21 jenis indeks saham, yang secara terus menerus disebarluaskan. Salah satu indeks yang dimiliki oleh Bursa Efek Indonesia adalah indeks sektoral yang merupakan subsektor dari Indeks Harga Saham Gabungan (IHSG). Indeks sektoral terdiri dari 9 sektor yaitu pertanian, pertambangan, industri dasar, aneka industri, industri barang konsumsi, properti, infrastruktur, keuangan, perdagangan dan jasa.

Penelitian ini menggunakan salah satu dari indeks sektoral, yaitu indeks harga saham sektor properti dan real estate. Indeks harga saham sektoral merupakan indikator yang menggambarkan pergerakan harga saham berdasarkan sektor usahanya. Informasi yang dihasilkan dari pergerakan indeks harga saham sektoral ini sangat diperlukan bagi investor dalam pengambilan keputusan investasi pembentukan portofolio. Sektor properti adalah salah satu sektor yang dapat menggambarkan keadaan terutama perekonomian suatu negara apakah ekonomi dalam keadaan yang baik atau tidak, dikatakan demikian karena sektor ini merupakan sektor utama dalam menciptakan kesejahteraan masyarakat (Ramadani, 2016). Saham properti bisa menjadi salah satu investasi yang tepat sesuai dengan kondisi perekonomian saat ini karena return yang akan diterima oleh investor cukup tinggi, sehingga ini menjadi daya tarik tersendiri bagi investor.

Pasar modal perusahaan sektor properti dan real estate di Indonesia saat ini berkembang dengan cepat. Berita ini ditandai dengan banyaknya perusahaan properti dan real estate yang go public di Indonesia. Berdasarkan penelitian yang dilakukan oleh Frank (2014), dalam laporan Prime Global Cities Index, Jakarta adalah kota dengan indeks harga properti tertinggi di dunia. Harga properti segmen atas meliputi proyek perumahan dan apartemen mewah mengalami peningkatan sebesar $23.7 \%$. Namun, harga saham properti dan real estate beberapa tahun terakhir mengalami fluktuasi. Fenomena naik turunnya harga saham sektor properti dan real estate, mengakibatkan investor cenderung melakukan pertimbangan dengan menganalisis pergerakan harga saham untuk melakukan keputusan investasi.

\section{Metode}

Metode yang digunakan dalam penelitian ini adalah metode deskriptif kuantitatif. Metode analisis ini digunakan untuk menguraikan suatu keadaan atau persoalan yang didukung oleh fakta, sifat-sifat serta hubungan antara fenomena yang dianalisis. Analisis ini digunakan untuk melihat secara empiris pengaruh variabel bebas (inflasi, kurs, suku bunga deposito dan PDB) terhadapvariabel tidak bebas (indeks harga saham sektor properti dan real estate). Analisis ini untuk mengetahui arah hubungan antara variabel bebas dengan variabel tidak bebas, apakah masing-masing variabel bebas berhubungan positif atau negatif terhadap variabel tidak bebas.

Jenis data yang digunakan dalam penelitian ini merupakan data sekunder yang disajikan dalam bentuk data tahunan atau data berkala (time series). Data sekunder adalah merupakan data yang telah dikumpulkan atau diolah melalui penelitian atau survey yang dilakukan oleh instansi, badan atau lembaga tertentu, atau dapat juga diperoleh dengan membaca buku atau literature lainnya yang terdiri dari buku-buku dan bulletin. Data sekunder 
tersebut yang dikumpulkan bersumber dari lembaga-lembaga seperti Badan Pusat Statistik (BPS), Bank Indonesia (Statistik Ekonomi dan keuangan Indonesia dan laporan perekonomian Indonesial), Bursa Efek Indonesia (BEI) (IDX statistics) dan instansi lain yang terkait dengan penelitian.

Metode analisis yang digunakan dalam penelitian ini adalah analisis deskriptif kuantitatif. Metode analisis deskriptif kuantitatif ini digunakan untuk menguraikan suatu keadaan atau persoalan yang didukung oleh fakta, sifat-sifat serta hubungan antara fenomena yang dianalisis. Analisis ini digunakan untuk melihat secara empiris pengaruh variabel bebas (inflasi, kurs, suku bunga deposito dan PDB) terhadapvariabel tidak bebas (indeks harga saham sektor properti dan real estate). Analisis ini untuk mengetahui arah hubungan antara variabel bebas dengan variabel tidak bebas, apakah masing-masing variabel bebas berhubungan positif atau negatif terhadap variabel tidak bebas. Adapun fungsi persamaan umumnya adalah sebagai berikut:

\section{IHSSP = f (Inf, Kurs, SB deposito, PDB)}

Alat analisis yang digunakan adalah persamaan regresi linear berganda dengan persamaan umum sebagai berikut (Junaidi, 2015):

$\mathrm{Y}=\boldsymbol{\beta}_{0}+\beta_{1} X_{1}+\beta_{2} X_{2}+\beta_{3} X_{3}+\beta_{4} X_{4}+e$

Persamaan tersebut kemudian ditransformasikan kedalam bentuk semi log (linear-log) dengan fungsi persamaan sebagai berikut:

$$
\text { IHSSP }=\beta_{0}+\beta_{1} \text { Inf }+\beta_{2} \operatorname{LogKurs}+\beta_{3} \mathrm{SB}+\beta_{4} \operatorname{LogPDB}+\mathrm{e}
$$

Keterangan:

$\begin{array}{ll}\text { IHSSP } & =\text { Indeks harga saham sektor properti dan real estate } \\ \beta 0 & =\text { Konstanta } \\ \beta 1, \beta 2, \beta 3, \beta 4 & =\text { Koefisien elastisitas } \\ \text { Inf } & =\text { Infasi } \\ \text { Log Kurs } & =\text { Logaritma nilai tukar rupiah terhadap US\$ } \\ \text { SB } & =\text { Tingkat suku bunga deposito } \\ \text { Log PDB } & =\text { Logaritma Produk Domestik Bruto } \\ \mathrm{e} & =\text { Error term }\end{array}$

\section{Hasil dan Pembahasan}

\section{Perkembangan Inflasi di Indonesia Tahun 2014-2018}

Salah satu prasyarat agar terjadi pertumbuhan ekonomi yang berkesinambungan adalah adanya kondisi inflasi yang rendah dan stabil. Oleh karenanya penting kebijakan pengendalian inflasi agar tidak memberikan dampak negatif kepada kondisi sosial ekonomi masyarakat.

Tabel 1. Perkembangan Inflasi di Indonesia Tahun 2014-2018

\begin{tabular}{cc}
\hline Tahun & Inflasi (\%) \\
\hline 2014 & 8,36 \\
2015 & 3,35 \\
2016 & 3,02 \\
2017 & 3,61 \\
2018 & 3,13 \\
\hline Rata-rata & $\mathbf{4 , 2 9}$ \\
\hline
\end{tabular}

Sumber: Statistik Ekonomi dan Keuangan Indonesia, 2018 (diolah)

Tahun 2015, kondisi inflasi ini Indonesia memasuki babak baru, dimana kondisi inflasi mulai terkendali. Inflasi tercatat sebesar 3,35 persen dan berada dalam kisaran inflasi 
yaitu $4 \pm 1 \%$. Kondisi ini dikarenakan turunnya harga minyak global secara drastis sejak pertengahan tahun 2014 karena permintaan global yang melemah, sedangkan pasokan minyak kuat karena tingginya produksi di negara-negara OPEC serta revolusi gas shale AS. Penurunan tersebut dimungkinkan sejalan dengan reformasi energi yang mengatur penentuan harga energi berdasarkan keekonomiannya. Kondisi ini mendorong rendahnya inflasi bahan pangan pada tahun 2015. Dari sisi domestik, kondisi inflasi yang terkendali tersebut tidak lepas dari permintaan domestik yang terkelola dan inflasi harga barang impor yang relatif rendah. Pergerakan Inflasi pada tahun 2015-2018 relatif stabil dan berada di bawah sasaran inflasi.

Inflasi pada tahun 2018 mengalami penurunan menjadi 3,13 persen dari tahun 2017. Laju inflasi tahun 2018 cukup terkendali meskipun harga bahan bakar minyak naik dan kondisi nilai tukar rupiah yang semakin terpuruk. Ada beberapa faktor pendorong semakin terkendalinya laju inflasi hingga akhir tahun 2018 diantaranya adanya koordinasi yang erat antara pemerintah pusat dan daerah yang dianggap mampu menjaga stabilitas harga pada sejumlah komoditas. Kondisi ini tercermin dari beberapa kelompok makanan yang inflasinya terkendali dengan baik. Pertumbuhan ekonomi yang terus meningkat meski melambat juga dinilai memberi dampak positif terhadap laju inflasi. Rendahnya tingkat inflasi beberapa tahun terakhir ini dapat menjadi sebuah tanda bahwa Indonesia telah memasuki era baru tingkat inflasi.

\section{Perkembangan Nilai Tukar di Indonesia}

Nilai tukar (kurs) adalah harga mata uang suatu negara terhadap mata uang negara lainny. Nilai tukar dalam penelitian ini adalah nilai tukar tengah (kurs tengah) rupiah terhadap dolar. Penggunaan nilai kurs tengah pada penelitian ini karena kurs tengah, karena kurs tengah ini seringkali digunakan perusahaan asing yang beraktivitas di Indonesia.

Bank Indonesia memiliki tujuan untuk mencapai dan memelihara kestabilan nilai rupiah. Kestabilan yang dimaksud adalah kestabilan rupiah terhadap harga barang yang tercermin dari laju inflasi dan kestabilan rupiah terhadap mata uang asing yang tercermin dari nilai tukar. Adapun data perkembangan nilai tukar rupiah terhadap dolar Amerika adalah sebagai berikut:

Tabel 2. Perkembangan Nilai Tukar di Indonesia Tahun 2014-2018

\begin{tabular}{ccc}
\hline Tahun & Nilai Tukar (Kurs) & Perkembangan (\%) \\
\hline 2014 & 12,440 & - \\
2015 & 13,795 & 10.89 \\
2016 & 13,436 & -2.60 \\
2017 & 13,548 & 0.83 \\
2018 & 14,072 & 3.87 \\
\hline Rata-rata & & $\mathbf{3 . 0 1}$
\end{tabular}

Sumber : Statistik Ekonomi dan Keuangan Indonesia, 2018 (diolah)

Ketidakpastian pasar keuangan global berdampak pada meningkatnya tekanan depresiasi nilai tukar rupiah pada tahun 2015. Rupiah mengalami pelemahan hingga pada posisi Rp 13,795/US\$. Dinamika triwulan nilai tukar rupiah terutama dipengaruhi oleh faktor eksternal yaitu ketidakpastian kenaikan suku bunga Fed Fun Rate (FFR), kekhawatiran negoisasi fiskal yunani, dan devaluasi yuan. Tekanan depresiasi rupiah dari eksternal ini diperberat oleh kondisi domestik yang diwarnai oleh melemahnya prospek pertumbuhan ekonomi domestik serta tingginya ketergantungan korporasi terhadap pembiayaan eksternal. Di sisi lain, kondisi pasar valas domestik yang belum dalam serta ketergantungan korporasi pada pembiayaan eksternal turut mengamplifikasi dampak tekanan ekternal pada rupiah.

Secara umum, kondisi nilai tukar rupiah pada tahun 2016 menunjukkan adanya penguatan dengan disertai menurunnya volatilitas nilai tukar. Pada tahun 2016, nilai tukar 
rupiah mengalami sedikit mengalami apresiasi secara year to year dari posisi Rp 13,795/US\$ menjadi Rp 13,463/US\$ di akhir tahun. Penguatan nilai tukar rupiah ini dipengaruhi oleh membaiknya kinerja Neraca pembayaran Indonesia (NPI). Selain itu, meningkatnya aliran modal asing turut menguatkan nilai tukar rupiah. Secara umum, nilai tukar rupiah pada tahun 2017 menunjukkan adanya kestabilan dan cenderung mengalami depresiasi. Secara year on year rupiah sedikit terdepresiaasi dari posisi Rp 13.379/US\$ pada 2016 menjadi Rp 13,548/US\$ pada 2017. Melemahnya nilai rupiah ini disebabkan oleh perkembangan positif perekonomian, politik dan kebijakan moneter di AS. Fakta tersebut membuat penguatan US\$ yang memicu pada tekanan depresiasi mata uang negara berkembang, termasuk rupiah.

Kondisi nilai tukar hingga akhir tahun 2018 kondisi nilai rupiah semakin terpuruk, secara yeor to year nilai tukar rupiah mengalami depresiasi hingga mencapai posisi Rp 14,072/US\$ di akhir tahun.Tekanan terhadap rupiah kembali meningkat seiring kuatnya ketidakpastian pasar keuangan global, hal ini memicu penguatan dolar AS secara meluas. Jika melihat rata-rata nilai tukar rupiah 18 tahun kebelakang, tahun 2018 rupiah memang mengalami pelemahan yang cukup dalam. Selain itu pelemahan nilai tukar rupiah ini juga disebabkan oleh neraca perdagangan yang defisit yang kemudian berimbas pada defisit neraca transaksi berjalan.

\section{Perkembangan Tingkat Suku Bunga Deposito}

Suku bunga merupakan salah satu variabel yang paling banyak diamati dalam perekonomian. Pergerakan suku bunga dapat mempengaruhi tingkat kesehatan perekonomian suatu negara. Suku bunga mempengaruhi keputusan seseorang untuk lebih banyak membelanjakan uangnya atau digunakan untuk beinvestasi agar memperoleh keuntungan dimasa yang akan datang. Deposito adalah salah satu produk perbankan berupa jasa tabungan yang menawarkan suku bunga tetap sesuai dengan jangka waktu yang telah ditetapkan. Kenaikan suku bunga deposito menyebabkan kecendrungan investor semakin banyak berinvestasi pada deposito.

Tabel 3. Perkembangan Tingkat Suku Bunga Deposito Periode 12 Bulan Tahun 2014-2018

\begin{tabular}{cc}
\hline Tahun & Suku Bunga Deposito (\%) \\
\hline 2014 & 8.79 \\
2015 & 8.47 \\
2016 & 7.31 \\
2017 & 6.79 \\
2018 & 6.41 \\
\hline Rata-rata & $\mathbf{7 . 5 5}$ \\
\hline
\end{tabular}

Sumber : Statistik Ekonomi dan Keuangan Indonesia, 2018 (diolah)

Kebijakan moneter bias ketat sepanjang tahun 2014 mampu menjangkar pembentukan ekspektasi inflasi pelaku ekonomi, tercermin pada ekspektasi inflasi yang terus menurun. Dari jalur suku bunga, transmisi ke suku bunga deposito tercermin pada kenaikan suku bunga deposito. Suku bunga deposito tenor 12 bulan mengalami peningkatan menjadi 8,79 persen dibandingkan tahun sebelumnya pada posisi 6,89 persen, atau meningkat sebesar 27,58 persen. Pada akhir tahun 2015 suku bunga deposito sedikit mengalami penurunan hingga sampai pada posisi 8,47 persen atau secara point-to-point turun sebesar 0,32 poin.

Kebijakan moneter Bank Indonesia pada tahun 2016 diarahkan untuk mengoptimalkan momentum pemulihan ekonomi, sambil tetap konsisten menjaga stabilitas ekonomi. Sejalan dengan arah kebijakan tersebut, Bank Indonesia menurunkan suku bunga kebijakan pada tahun 2016. Disisi lain, penurunan suku bunga kebijakan diharapkan menopang pemulihan Secara keseluruhan, suku bunga kebijakan diturunkan sebesar 150 poin (Bank Indonesia, 2016). Kondisi ini kemudian mendorong penurunan suku bunga deposito 
sebesar $-13,70$ persen atau turun dari posisi 8,47 persen di tahun 2015 menjadi 7,13 persen diakhir tahun 2016. Penurunan suku bunga deposito juga diikuti oleh penurunan suku bunga kredit, meskipun dengan besaran yang lebih kecil. Penurunan suku bunga deposito yang lebih besar dibandingkan dengan penurunan suku bunga kredit berdampak pada melebarnya spread suku bunga deposito dan suku bunga kredit.

Kebijakan moneter yang dilakukan Bank Indonesia sepanjang tahun 2017 searah dengan upaya menjaga inflasi dalam kisaran sasarannya dan mengendalikan defisit transaksi berjalan. Pada awal tahun 2017, Bank Indonesia tetap mempertahankan suku bunga acuan (BI 7-day RR Rate) sebesar 4,75 persen.Dalam menentukan kebijakan, Bank Indonesia selalu mempertimbangkan ruang pelonggaran kebijakan moneter yang tersedia. Pada semester II 2017, ruang pelonggaran yang tersedia dimanfaatkan untuk menurunkan suku bunga kebijakan pada bulan Agustus dan September 2017 masing-masing sebesar 25 bps. Pada Agustus 2017, BI 7-day RR Rate diturunkan dari 4,75 persen menjadi 4,50 persen. Pada September 2017, BI 7-day RR Rate diturunkan dari 4,50 persen menjadi 4,25 persen (Bank Indonesia, 2017). Penurunan suku bunga acuan pada kedua bulan tersebut diikuti dengan penurunan suku bunga instrumen moneter lainnya seperti suku bunga deposito yang turun menjadi 6.79 persen dari posisi 7,13 persen.

Secara year-on-year suku bunga deposito sedikit mengalami penurunan menjadi 6.41 persen di tahun 2018. Penurunan suku bunga deposito ini dikarenakan adanya penurunan suku bunga acuan Bank Indonesia. Pergerakan suku bunga deposito yang cukup stabil ini dikarenakan suku bunga acuan Bank Indonesia yang tetap berada pada posisi 4,25 persen atau stabil hingga akhir tahun. Deposito masih menjadi instrumen investasi yang diminati masyarakat. Selain suku bungannya lebih besar dari tabungan biasa, risiko investasi deposito juga rendah. Namun, jika dibandingkan dengan investasi pada pasar saham dengan risiko yang lebih tinggi, maka investasi pada saham lebih menguntungkan.

\section{Perkembangan Produk Domestik Bruto (PDB) Indonesia}

Salah satu indikator penting untuk mengetahui kondisi ekonomi suatu negara dalam suatu periode tertentu adalah PDB (Zamzami dkk. 2020). PDB adalah nilai pasar semua barang dan jasa yang diproduksi oleh suatu negara pada periode tertentu. Data PDB yang digunakan dalam penelitian ini adalah data PDB tahun 2000-2018. Data PDB tahun 2000 hingga tahun 2010 digunakan tahun dasar 2000, sedangkan tahun 2011 hingga tahun 2018 digunakan tahun dasar 2010. Data PDB tersebut dilakukan penyesuaian dengan menggunakan tahun dasar 2010. Penyesuaian ini dilakukan agar tidak terjadi kesalahan dalam penggunaan data PDB baik PDB yang menggunakan tahun dasar 2000 maupun tahun dasar 2010.

Tabel 4. Perkembangan Produk Domestik Bruto (PDB) Indonesia tahun 2014-2018

\begin{tabular}{ccc}
\hline Tahun & PDB (Miliar Rupiah) & Perkembangan (\%) \\
\hline 2014 & $8,564,866$ & - \\
2015 & $8,982,517$ & 4.88 \\
2016 & $9,434,613$ & 5.02 \\
2017 & $9,912,703$ & 5.09 \\
2018 & $10,425,316$ & 5.17 \\
\hline Rata-rata & & $\mathbf{5 . 0 3}$ \\
\hline
\end{tabular}

Sumber : Statistik Ekonomi dan Keuangan Indonesia, 2018 (diolah)

Pertumbuhan ekonomi pada tahun 2014 mengalami moderasi pertumbuhan. Hal tersebut merupakan imbas dinamika global yang tidak sesuai perkiraan dan kebijakan stabilisasi yang diterapkan oleh Bank Indonesia dan pemerintah. Meskipun termoderasi pertumbuhan ekonomi Indoensia dapat tumbuh sebesar 5,01 persen, masih lebih tinggi dibandingkan dengan pertumbuhan ekonomi ASEAN yang rata-rata pertumbuhannya sebesar 4,7 persen (Bank Indonesia, 2014). 
Tahun 2015, pertumbuhan PDB Indonesia mengalami penurunan menjadi 4,88 persen. Ketidakseimbangan pemulihan ekonomi global mengakibatkan terjadinya divergensi siklus kebijakan moneter antar berbagai negara. Kemerosotan harga komoditas semakin berdampak kepada buruknya kinerja perekonomian negara berkembang dan ketidakpastian mengenai kecepatan dan besarnya kenaikan suku bunga di Amerika Serikat menjadi dua kekuatan utama yang mewarnai gejolak dipasar keuangan global selama tahun 2015, yang pada gilirannya berdampak pada menurunnya arus modal ke negara berkembang termasuk Indonesia.

PDB pada tahun 2016 tumbuh sebesar 5,02 persen, lebih tinggi dari tahun 2015 yang tumbuh sebesar 4,88 persen. Perbaikan ekonomi pada 2016. Perekonomian Indonesia terus menujukkan kinerja yang membaik dan melanjutkan perkembangan positif pertumbuhan ekonomi Indonesia, dimana pertumbuhan PDB Indonesia pada tahun 2017 mencapai 5,07 persen. Angka ini, menurut BPS, merupakan angka pertumbuhan ekonomi tertinggi sejak tahun 2014 silam. Sumber pertumbuhan ekonomi pada tahun 2017 adalah industri pengolahan, yakni sebesar 0,91 persen. Selain itu disusul sektor kontruksi sebesar 0,67 persen, perdagangan 0,59 persen, dan pertanian 0,49 persen. Dari sisi pengeluaran pertumbuhan ini dipengaruhi oleh peningkatan ekspor sebagai dampak positif pemulihan ekonomi dunia, yang pada akhirnya meningkatkan harga komoditas. Selain itu peningkatan impor bahan baku dan barang modal digunakan untuk mendukung investasi dan produksi dalam negeri.

Tahun 2018, PDB Indonesia tumbuh sebesar 5,17 persen lebih tinggi dibandingkan tahun sebelumnya yang tumbuh sebesar 5,09 persen. Permintaan domestik terutama dari sisi rumah tangga, investasi dan konsumsi pemerintah masih menjadi motor penggerak utama pertumbuhan ekonomi tahun 2018. Faktor eksternal juga menjadi salah satu dorongan utama pertumbuhan PDB tahun ini terutama melalui kenaikan harga komoditas. Struktur pertumbuhan ekonomi kuartal II-2018, berdasarkan pengeluran masih di dominasi oleh sektor rumah tangga dengan andil 55,43 persen yang tumbuh 5,14 persen.

\section{Perkembangan Indeks Harga Saham Sektor Properti dan Real Estate}

Indeks harga saham secara terus menerus dipublikasikan melalui berbagai media, baik media cetak maupun media elektronik sebagai salah satu sumber informasi bagi investor. Setiap informasi dan perkembangan transaksi di bursa di butuhkan oleh investor sebagai pertimbangan untuk melakukan keputusan investasi atau tidak di bursa. Bursa Efek Indonesia memiliki beberapa jenis indeks sektoral salah satunya indeks sektor properti dan real estate. Sektor ini terdiri dari sub sektor properti dan real estate dan sub sektor kontruksi bangunan.

Tabel 5. Indeks Harga Saham Sektor Properti dan Real Estate Tahun 2014-2018

\begin{tabular}{ccc}
\hline Tahun & Indeks Harga Saham & Perkembangan (\%) \\
\hline 2014 & 524,91 & - \\
2015 & 490,93 & -6.47 \\
2016 & 517,81 & 5.48 \\
2017 & 495,51 & -4.31 \\
2018 & 447,75 & -9.64 \\
\hline Rata-rata & & $\mathbf{2 4 . 0 7}$ \\
\hline
\end{tabular}

Tahun 2014, prospek industri properti dan real esate sangat menggembirakan karena ditopang oleh realisasi program Masterplan Percepatan dan Perluasan Pembangunan Ekonomi Indonesia (MP3EI) dalam jangka panjang serta kucuran dana investasi langsung (direct investment), baik dari dalam negeri maupun investor asing dalam negeri yang dipastikan meningkat setelah pemilu. Indeks harga saham sektor properti dan real esate 
mengalami peningkatan sebesar 524,91 poin dimana pada tahun 2013 berada pada posisi 337 poin atau mengalami peningkatan sebesar 55,76 persen.

Kinerja emiten properti sepanjang tahun 2015 mengalami perlambatan lantaran dihadapkan dengan tantangan berat. Lesunya kondisi ekonomi dan gejolak nilai tukar membuat pendapatan maupun laba bersih emiten sektor ini tergerus. Indeks harga saham mengalami penurunan sebesar $-6,47$ persen, dimana terjadi penurunan indeks harga saham dari posisi 524,91 poin menjadi 490,93 poin pada tahun 2015. Penurunan indeks harga saham sektor properti ini dikarenakan adanya penurunan daya beli masyarakat. Data Bank Indonesia menunjukkan penjualan properti residensial pada kuartal IV-2014 tumbuh hingga 40,07 persen setelah itu turun menjadi 26,62 persen di kuartal I-2015.

Berdasarkan hasil survey Properti affordability Sentiment Index pada tahun 2015 yang dilakukan oleh portal properti rumah.com, mengungkapkan bahwa masyarakat masih meminati pasar properti pada tahun 2016. Hasil ini menunjukkan pandangan positif masyarakat terhadap kondisi properti Indoensia tahun 2016 seiring membaiknya kondisi perekonomian. Infrastruktur yang di bangun pemerintah juga ikut memberi pengaruh penting dalam meningkatkan keyakinan konsumen properti dalam mengambil keputusan berinvestasi. Pelonggaran lanjutan kebijakan LTV/FTV pada 2016 mulai berdampak meningkatkan pertumbuhan kredit properti. Kondisi ini diikuti oleh pergerakan indeks harga saham yang meningkat menjadi 517,81 poin di akhir tahun 2016, atau mengalami peningkatan sebesar 5,48 persen.

Tahun 2017 hingga 2018, indeks harga saham sektor properti dan real estate mengalami penurunan. Pada tahun 2018 indeks harga saham berada pada posisi 447,75 poin menurun dari posisi 495,51 ditahun 2017. Kinerja sektor properti sepanjang 2 tahun terakhir tidak terlalu menggembirakan. Harapan 2017 sebagai tahun pemulihan rupanya belum cukup terbukti dan mendorong nilai saham emiten-emiten di sektor ini terdepresiasi. Berdasarkan data Bursa Efek Indonesia, indeks sektor properti, real estate dan kontruksi bangunan sepanjang tahun 2017 turun 4,31 persen di saat IHSG justru melonjak 19,99 persen. Kinerja sektor properti tidak terbukti membaik meski suku bunga Bank Indonesia turun dan kebijakan loan to deposit ratio diperlonggar. Kondisi ini dikarena pada saat yang bersamaan, terdapat potensi peningkatan suku bunga KPR yang ditambah dengan adanya pelambatan pertumbuhan ekonomi akibat adanya kenaikan suku bunga. Apalagi dengan harga jual properti yang kini cukup mahal dan tak diimbangi dengan daya beli masyarakat.

Performa saham-saham properti mengalami penurunan setelah bulan Juni 2018, kondisi ini disebabkan oleh adanya kenaikan suku bunga dan pelemahan demand akibat tahun pemilu 2019. Pada akhirnya menjadi ekspektasi negatif saham-saham di bursa termasuk sektor properti. Bagi investor jangka panjang, emiten properti layak untuk di koleksi. Selain itu, adanya keyakinan proyeksi indutri properti pada tahun-tahun berikutnya juga cukup positif setelah didera kelesuan beberapa tahun terakhir. Akan tetapi, bagi investor yang ingin meraup keuntungan dalam jangka pendek tentunya sektor properti ini tidak cukup menarik untuk dijadikan pilihan investasi.

\section{Model Pengaruh Variabel Makroekonomi Terhadap Indeks Harga Saham Sektor Properti dan Real Estate di Bursa Efek Indonesia}

Estimasi pengaruh variabel makroekonomi terhadap indeks harga saham sektor properti dan real estate di Bursa Efek Indonesia diberikan pada Tabel 6. 
Tabel 6. Estimasi Model

\begin{tabular}{lcccc}
\hline \multicolumn{1}{c}{ Variabel } & Coefficient & Std. Error & t-Statistic & Prob \\
\hline C & -5296.497 & 1254.221 & -4.222937 & 0.0009 \\
INF & -11.44170 & 3.930532 & -2.910979 & 0.0114 \\
KURS & 486.0151 & 134.0947 & 3.624416 & 0.0028 \\
SB & -16.73707 & 7.725997 & -2.166332 & 0.0480 \\
PDB & 80.82252 & 129.2635 & 0.625254 & 0.5419 \\
R-squared & 0.941270 & F-statistic & & 56.09505 \\
Adjusted R-Squared & 0.924490 & Prob (F-Statistic) & & 0.000000 \\
\hline
\end{tabular}

Sumber: Data diolah, 2019

\section{Uji Asumsi Klasik}

Uji asumsi klasik dari model terdiri dari uji multikolinearitas, heterokedastisitas, autokorelasi dan normalitas.

\section{Uji Multikolinearitas}

Multikolinearitas dideteksi melalui pengujian koefisien korelasi (r) antara variabel independen.Jika koefisien korelasi cukup tinggi (diatas 0,85), di duga ada multikolinearitas dalam model. Sebaliknya jika koefisien korelasi relatif rendah, diduga model tidak mengandung masalah multikolinearitas (Widarjono, 2013).

Tabel 7. Uji Multikolinearitas

\begin{tabular}{ccccc}
\hline & INF & LOG(KURS) & SB & LOG(PDB) \\
\hline INF & 1.000000 & -0.256229 & 0.556690 & -0.589854 \\
LOG(KURS) & -0.256229 & 1.000000 & -0.455788 & 0.779890 \\
SB & 0.556690 & -0.455788 & 1.000000 & -0.833409 \\
LOG(PDB) & -0.589854 & 0.779890 & -0.833409 & 1.000000 \\
\hline
\end{tabular}

Sumber: Data diolah, 2019

Berdasarkan Tabel 7 menunjukkan model lolos dari masalah multikolinearitas. Nilai koefisien korelasi variabel inflasi, nilai tukar, suku bunga deposito dan pertumbuhan PDB lebih kecil dari 0,85 ..

\section{Uji Heterokedastisitas}

Pendeteksian heterokedastisitas dalam penelitian ini menggunakan metode White. Yaitu dengan dengan melihat nilai chi square hitung yang diperoleh dari nilai Obs*R-squared yaitu jumlah obsevasi dikalikan koefisien determinasi. Jika nilai chi squarehitung $\left(X^{2}\right)<$ nilai kritis chi square $\left(X^{2}\right)$ maka dapat disimpulkan tidak ada masalah heterokedastisitas.

Tabel 8. Uji Heterokedastisitas

\begin{tabular}{lcll}
\hline F-statistic & 0.404563 & Prob. F(12,6) & 0.9141 \\
Obs*R-squared & 8.497693 & Prob. Chi-Square(12) & 0.7451 \\
Scaled explained SS & 3.530188 & Prob. Chi-Square(12) & 0.9905 \\
\hline
\end{tabular}

Sumber: Data diolah, 2019

Hasil pengujian uji heterokedastisitas nilai Chi-square hitung sebesar 0.7451 yang diperoleh dari informasi Obs*R-squared. Sedangkan nilai Chi-square hitung pada $\alpha=5 \%$ dengan df sebesar 14 adalah 23.68479. Karena nilai $x^{2}$ hitung $<$ nilai $x^{2}$ tabel (23.68479), maka dapat disimpulkan tidak ada masalah heterokedastisitas. Hasil perhitungan dapat diketahui bahwa bilai probability F-hitung sebesar 0.787184 lebih besar dari tingkat alpha $0,05(5 \%)$, dengan demikian tidak terjadi masalah heterokedastisitas.

\section{Uji Autokorelasi}

Menurut Junaidi (2015), autokorelasi didefinisikan sebagai korelasi antara anggota serangkaian observasi yang diurutkan menurut waktu (dalam data time series) atau ruang (dalam data cross-section). Dalam konteks regresi, model regresi linear klasik mengasumsikan bahwa autokorelasi itu tidak terdapat dalam disturbance atau gangguan ui. 
Autokorelasi lebih sering terjadi pada data time-series dibandingkan data cross-section. Penyebab utama terjadinya terjadinya autokorelasi adalah adanya variabel penting yang tidak digunakan dalam model. Pendeteksian autokorelasi dapat dilihat dari probabilitas $o b s^{*} \mathrm{R}^{2}$ dengan statistik breush-Godfrey Serial Corelation LM Test.

Tabel 9. Uji Autokorelasi

\begin{tabular}{llll}
\hline \hline F-statistic & 0.416410 & Prob. $\mathrm{F}(2,12)$ & 0.6686 \\
Obs ${ }^{*}$ R-squared & 1.233055 & Prob. Chi-Square (2) & 0.5398 \\
\hline \hline
\end{tabular}

Sumber: Data diolah, 2019

Hasil pengujian LM diketahui besarnya nilai $\mathrm{x}^{2}$ hitung sebesar 0.5398 diperoleh dari Obs*R-squared. Sedangkan nilai $x^{2}$ tabel dengan df 14 pada $\alpha=5 \%$ sebesar 23.68479 . Nilai $x^{2}$ hitung (0.6331) < nilai $\mathrm{x}^{2}$ tabel (23.68479). Maka dapat disimpulkan bahwa model lulus dari masalah autokorelasi. Berdasarkan tabel hasil uji autokorelasi diketahui bahwa nilai probabilitas F $(2,12)$ sebesar $0.6686>0.05(5 \%)$ sehingga dapat disimpulkan tidak terjadi autokorelasi.

\section{Uji Normalitas}

Uji normalitas dalam penelitian ini menggunakan test normality pada residual test histogram yang dikembangkan oleh Jarque Bera (JB) (Widarjono, 2015).

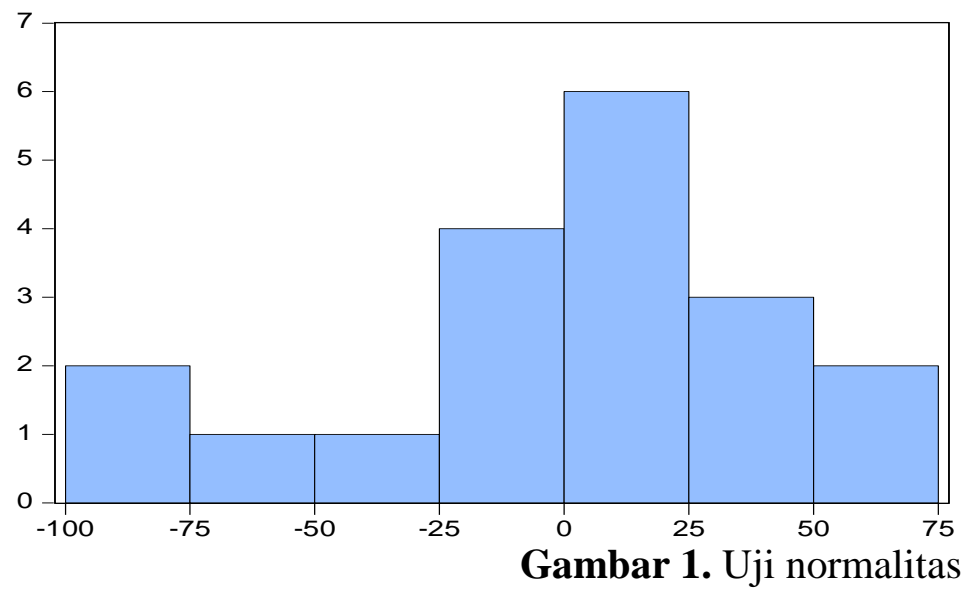

\begin{tabular}{|lr|}
\hline \multicolumn{2}{|l|}{ Series: Residuals } \\
Sample 2000 2018 \\
Observations 19 \\
Mean & $-5.37 e-13$ \\
Median & 14.05483 \\
Maximum & 55.50168 \\
Minimum & -83.61864 \\
Std. Dev. & 41.32903 \\
Skewness & -0.635969 \\
Kurtosis & 2.530305 \\
& \\
Jarque-Bera & 1.455430 \\
Probability & 0.483011 \\
\hline
\end{tabular}

Sumber: data diolah 2019

Berdasarkan hasil perhitungan uji J-B diketahui besarnya nilai J-B sebesar 1.45430 < 23.68479 nilai Chi-square $\left(x^{2}\right)$ pada $\alpha=5 \%$ adalah 23.68479. artinya model lolos dari ketidaknormalan distribusi residual. Bila dilihat dari probabilitas J-B hitung sebesar 0.483011 $>0.05$, sehingga dapat disimpulkan bahwa residual terdistribusi normal yang artinya asumsi klasik tentang kenormalan terpenuhi.

\section{Pengujian Hipotesis Secara Simultan (Uji-F)}

Uji F statistik dilakukan untuk melihat pengaruh variabel independen yaitu inflasi, nilai tukar, suku bunga deposito dan pertumbuhan PDB terhadap variabel dependen yaitu indeks harga saham sektor properti dan real estate. Berdasarkan hasil regresi secara simultan diperoleh nilai F-hitung sebesar 56.09505sedangkan F-tabel 3,11. Pada tingkat keyakinan 95\% $(\alpha=5 \%)$ dengan demikian F-hitung >F-tabel yaitu 56.09505> 3,11 artinya secara bersama-sama variabel inflasi, nilai tukar, suku bunga deposito dan pertumbuhan PDB berpengaruh signifikan terhadap indeks harga saham sektor properti dan real estate selama periode 2000-2018. 


\section{Pengujian Hipotesis Secara Parsial (Uji-t)}

Uji-t dilakukan dengan membandingkan probabilitas t-hitung terhadap tingkat $\alpha=5 \%$. Jika probabilitas t-hitung $>\alpha(0,05)$, Ho diterima, yang artinya variabel independen tidak berpengaruh secara parsial terhadap variabel dependen. Sebaliknya jika probabilita t-hitung $\alpha$ $<0,05$, Ho ditolak, yang berarti variabel independen berpengaruh secara individual terhadap variabel dependen.

\section{Inflasi}

Nilai probabilitas variabel inflasi (INF) adalah 0,00114 lebih kecil dari tingkat alpha 0,05, jadi dapat disimpulkan bahwa inflasi berpengaruh negatif dan signifikan terhadap indeks harga saham sektor properti dan real estate selama periode 2000-2018. Temuan penelitian ini sejalan dengan temuan Hooker (2004) dan Kandir (2008). Namun demikian, temuan penelitian ini berbeda dengan temuan Kewal (2012), Gudono (2007) dan Mok (2004) yang menunjukkan tidak adanya pengaruh inflasi terhadap indeks harga saham

\section{Nilai Tukar}

Nilai probabilitas variabel nilai tukar (kurs) adalah 0.0028 lebih kecil dari tingkat alpha 0,05, jadi dapat disimpulkan bahwa nilai tukar (kurs) berpengaruh negatif dan signifikan terhadap indeks harga saham sektor properti dan real estate selama periode 20002018. Temuan penelitian ini sejalan dengan temuan Kewal (2012), Meta (2005), Desislava (2005), Sodikin (2007), Kusuma (2008), Permana \& Sularto (2008). Meskipun demikian, temuan penelitian ini berbeda dengan Wangbangpo dan Sharma (2002), Kandir (2008) yang menemukan tidak adanya pengaruh nilai tukar terhadap indeks harag saham.

\section{Suku Bunga Deposito}

Nilai probabilitas variabel suku bunga deposito (SB) adalah 0.0480 lebih kecil dari tingkat alpha 0,05, jadi dapat disimpulkan bahwa Suku Bunga Deposito (SB) berpengaruh negatif dan signifikan terhadap indeks harga saham sektor properti dan real estate selama periode 2000-2018. Temuan ini sejalan dengan temuan Hooker (2004) dan Chiarella dan Gao (2004), Kandir (2008). Tetapi temuan penelitian ini berbeda dengan temuan Kewal (2012) yang menunjukkan tidak adanya pengaruh inflasi terhadap indeks harga saham

\section{Produk Domestik Bruto}

Nilai probabilitas variabel produk domestik bruto (PDB) adalah 0.5419 lebih besar dari tingkat alpha 0,05, jadi dapat disimpulkanbahwa pertumbuhan PDB tidak berpengaruh signifikan terhadap indeks harga saham sektor properti dan real estate selama periode 20002018. Temuan penelitian ini sejalan dengan temuan Kewal (2012)

\section{Koefisien Determinasi $\left(\mathbf{R}^{2}\right)$}

Nilai $\mathrm{R}^{2}$ menunjukkan seberapa besar variabel independen berpengaruh terhadap variabel dependen, nilai $\mathrm{R}^{2}$ berkisar antara $0-1$. Nilai $\mathrm{R}^{2}$ makin mendekati 0 maka pengaruh semua variabel independen terhadap variabel dependen semakin kecil dan sebaliknya jika nilai $\mathrm{R}^{2}$ semakin mendekati 1 maka pengaruh semua variabel independen terhadap variabel dependen semakin besar. Berdasarkan hasil regresi, terlihat bahwa koefisien determinasi $\left(\mathrm{R}^{2}\right)$ sebesar 0.924490. Hal ini bearti 92,44 persen pergerakan indeks harga saham sektor properti dan real estate dipengaruhi oleh variabelinflasi, nilai tukar, suku bunga deposito dan laju pertumbuhan PDB. Sedangkan sisanya sebesar 7,56 persen dipengaruhi oleh variabel lain yang tidak dimasukkan ke dalam penelitian ini.

\section{Interpretasi Model}

Koefisien regresi variabel inflasi sebesar -11.44170 yang berarti setiap kenaikan inflasi sebesar 1 persen akan menurunkan indeks harga saham sektor properti dan real estate sebesar 11,44170 poin dengan asumsi variabel lain tetap atau tidak mengalami perubahan. Tingginya inflasi akan mendorong harga bahan bangunan menjadi semakin mahal, 
menyebabkan tingginya biaya produksi yang harus di tanggung oleh perusahaan. Seperti diketahui bahwa inflasi dapat menaikkan biaya produksi dan dapat membuat daya beli masyarakat akan menjadi menurun.

Koefisien regresi variabel nilai tukar sebesar 486.0151 yang berarti bahwa setiap kenaikan nilai tukar sebesar 1 persen akan menaikkan indeks harga saham sektor properti dan real estate sebesar 486,0151 poin dengan asumsi variabel lain tetap atau tidak mengalami perubahan. Nilai tukar yang postif dan signifikan disebabkan karena pada kenyataanya, apabila nilai tukar rupiah melemah (rupiah terdepresiasi), Indikator ini mengindikasikan kondisi perekonomian yang dalam keadaan kurang baik, sehingga investor enggan untuk berinvestasi pada saham. Berkurangnya investor akan menyebabkan harga saham menurun.

Koefisien regresi variabel suku bunga deposito sebesar -16.73707 yang berarti setiap kenaikan suku bunga deposito sebesar 1 persen akan menurunkan indeks harga saham sektor properti dan real estate sebesar 16,73707 poin dengan asumsi variabel lain tetap atau tidak mengalami perubahan.. Suku bunga akan mempengaruhi tingkat aktivitas ekonomi, sehingga dapat mempengaruhi laba perusahaan. Semakin tinggi tingkat suku bunga maka akan semakin besar beban yang akan ditanggung perusahaan terutama perusahaan yang banyak berhutang dari bank, sehingga berdampak pada penurunan profitabilitas perusahaan. Penurunan profit perusaahan akan membuat harga saham menjadi terguras karena kondisi ini berkaitan dengan return yang akan diperoleh investor. Selain itu, kenaikan suku bunga juga akan memicu minat orang menabung sekaligus mengurangi kredit bank.

Pertumbuhan PDB tidak berpengaruh signifikan terhadap indeks harga saham sektor properti dan real estate selama periode 2000-2018. Tidak berpengaruhnya PDB terhadap nilai indeks harga saham sektor properti ini menandakan bahwa meningkat dan menurunnya PDB Indonesia kurang dapat mempengaruhi minat investor untuk menanamkan modalnya. Keputusan investasi lebih dititikberatkan pada variabel yang berhubungan langsung dengan return yang akan diperoleh oleh investor seperti tingkat suku bunga, kondisi inflasi dan kondisi nilai tukar. Jika ditinjau dari sisi konsumen pembelian akan properti seperti perumahan tidak dipengaruhi oleh keadaan apakah perekonomian sedang tumbuh atau tidak karena kebutuhan properti merupakan kebutuhan pokok. Selain itu permintaan properti juga didukung oleh adanya Kredit Perumahan Rakyat (KPR).

\section{Kesimpulan dan Saran}

\section{Kesimpulan}

Selama periode 2000-2018, pergerakan indeks harga saham sektor properti dan real estate, inflasi, kurs, suku bunga deposito dan pertumbuhan PDB mengalami perkembangan yang berfluktuasi dengan perkembangan rata-rata 24,07 persen untuk indeks harga saham, inflasi mengalami perkembangan rata-rata sebesar 13,25 persen, kurs mengalami perkembangan rata-rata sebesar 2,62 persen, suku bunga deposito mengalami perkembangan rata-rata sebesar $-3,14$ persen dan pertumbuhan PDB mengalami perkembangan rata-rata sebesar 5,30 persen. Hasil penelitian menunjukkan bahwa variabel independen inflasi dan suku bunga deposito berpengaruh negatif dan signifikan terhadap pergerakan indeks harga saham sektor properti dan real estate. Variabel kurs berpengaruh positif dan signifikan terhadap pergerakan indeks harga saham sektor properti dan real estate, sedangkan variabel PDB berpengaruh positif dan tidak signifikan terhadap pergerakan indeks harga saham sektor properti dan real estate.

\section{Saran}

Otoritas moneter dalam mengendalikan pergerakan indeks harga saham memprioritaskan pada kebijakan stabilitas moneter khususnya kebijakan yang dapat 
menurunkan/mengendalikan tingkat inflasi dan tingkat suku bunga, sehingga memperkuat pengendalian dan stabilitas pasar saham di BEI. Pemerintah harus selalu mengambil langkahlangkah strategis untuk memperkuat tingkat kurs rupiah, karena penguatan kurs rupiah dapat memberikan sinyal positif bagi investor untuk berinvestasi pada pasar saham.

\section{Daftar Pustaka}

Adam, H., Hamzah, A., \& Musnadi, S. (2013). Analisis pengaruh nilai tukar, SBI, inflasi dan pertumbuhan GDP terhadap pergerakan indeks harga saham gabungan di Bursa Efek Indonesia. Jurnal Ilmu Ekonomi, 13, 16-28.

Bursa Efek Indonesia. (2015). Buku Panduan Indeks Harga Saham Bursa Efek Indonesia. BEI.

Chiarella C. \& Gao S. (2004). The Value of The S\&P 500 - A Macro View of The Stock Market Adjustment Process. Global Finance Journal. 15, 171-196

Desislava, D. (2005). The Relationship between Exchange Rates and Stock Prices: Studied in a Multivariate Model. Issues in Political Economy, 14.

Fahmi, I. (2015). Pengantar Pasar Modal. Alfabeta.

Gudono. (2007). Penilaian Pasar Modal terhadap Fluktuasi Bisnis Real Estate. Jurnal Kelola. 20/VIII.

Hooker, M. A. (2004). Macroeconomic Factors and Emerging Market Equity Returns: A Bayesian Model Selection Approach. Emerging Markets Review, 5, 379-387.

Junaidi. (2015). Ekonometrika I. Fakultas Ekonomi dan Bisnis Universitas Jambi.

Kandir, S.Y. (2008). Macroeconomic Variables, Firm Characteristics and Stock Returns: Evidence from Turkey. International Research Journal of Finance and Economics, $16,35-45$

Kewal, S.S. (2012). Pengaruh Inflasi, Suku Bunga, Kurs, Dan Pertumbuhan Pdb Terhadap Indeks Harga Saham Gabungan. Jurnal Economia, 8(1), 53 - 64

Knight Frank. (t.t.) Prime global cities index. Global Real Estate Consultants | Knight Frank. https://www.knightfrank.com/research/report-library/prime-global-cities-index-q12018-5503.aspx

Kusuma, B. H. (2008). Analisis pengaruh tingkat bunga SBI, Kurs Tengah BI dan Tingkat Inflasi dalam memprediksi indeks saham gabungan di Bursa Efek Jakarta. Jurnal Ekonomi, 8(3), 305-318.

Meta, R.S. (2005). Perbedaaan Pengaruh Inflasi, Tingkat Suku Bunga dan Nilai Tukar Rupiah/US Dollar Terhadap Return Saham. Jurnal Ekonomi STUE Surakarta.

Mok, H.M.K. (1993). Causality of Interest Rate, Exchange rate, and Stock price at Stock Market Open and close in Hong Kong. Asia Pacific Journal of Management. X, 123129

Otoritas Jasa Keuangan. (4 Oktober 2018). Laporan Tahunan OJK 2018. https://www.ojk.go.id/id/data-dan-statistik/laporan-tahunan/Pages/LaporanTahunan-OJK-2017.aspx

Permana,Y \& Sularto, L. (2009). Pengaruh Fundamental Keuangan, Tingkat Bunga, dan Tingkat Inflasi Terhadap Pergerakan Harga Saham. Jurnal Ekonomi dan Bisnis, 2(13), $103-111$

Ramadani, F. \& Sularto, L. (2016). Pengaruh inflasi, suku bunga dan nilai tukar rupiah terhadap harga saham perusahaan sektor properti dan real estate yang tercatat di Bursa Efek Indonesia. Manajemen Bisnis, 6(1).

Sodikin, A. (2007). Pengaruh Faktor Agregat Ekonomi Terhadap Return Saham. Jurnal Perspektif Ekonomi, 2(1), 60 - 89.

Widarjono, A. (2013). Ekonometrika Pengantar dan Aplikasi. UPP STIM YKPN. 
Wongbangpo, P. \& Subhash C. S. (2002). Stock Market and Macroeconomic Fundamental Dynamic Interaction: ASEAN-5 Countries. Journal of Asian Economics, 13,27-51. Zamzami, W., Junaidi, J. \& Prihanto, P.H. (2020). Pengaruh belanja modal dan investasi terhadap pertumbuhan ekonomi melalui kesempatan kerja di Provinsi Jambi. Jurnal Paradigma Ekonomika, 15(1), 115 - 124 